\title{
Difficulties in nutritional counseling and child growth follow-up: from a professional perspective
}

\author{
Dificuldades no aconselhamento nutricional e acompanhamento do crescimento infantil: \\ perspectiva de profissionais \\ Dificultades sobre el asesoramiento nutricional y el acompañamiento del crecimiento infantil \\ según la perspectiva de profesionales
}

\section{Claudia Nery Teixeira Palombo', Elizabeth Fujimori',", Áurea Tamami Minagawa Toriyama'"I, Luciane Simões Duarte', Ana Luiza Vilela Borges"}

'Universidade de São Paulo, Nursing School, Postgraduate Program in Nursing. São Paulo, Brasil.

"Universidade de São Paulo, Nursing School, Nursing Department of Collective Health. São Paulo, Brazil.

II' Universidade de São Paulo, Nursing School, Maternal-Child Nursing and Psychiatric Department. São Paulo, Brazil.

\section{How to cite this article:}

Palombo CNT, Fujimori E, Toriyama ATM, Duarte LS, Borges ALV. Difficulties in nutritional counseling and

child growth follow-up: from a professional perspective. Rev Bras Enferm [Internet]. 2017;70(5):949-57.

[Thematic Edition "Good practices and fundamentals of Nursing work in the construction of a democratic society"]

DOI: http://dx.doi.org/10.1590/0034-7167-2016-0527

Submission: 11-11-2016 Approval: 01-31-2017

\section{ABSTRACT}

Introduction: Nutritional counseling and growth follow-up are priorities when providing care to children; however, these have not been completely incorporated into primary health care. Objective: To know the difficulties for providing nutritional counseling and child growth follow-up, from a professional healthcare perspective. Method: Qualitative study, using Donabedian as theoretical framework, developed by 53 professionals in the field of primary health care. Data was obtained from focal groups and submitted to content analysis. Results: The main difficulties for nutritional counseling were clustered in the category of 'perceptions and beliefs related to child feeding'. The 'problems of infrastructure and healthcare' and 'maintenance of the hegemonic medical model' are the main difficulties for following-up growth. Final considerations: Besides investments in infrastructure, healthcare training is indispensable considering beliefs and professional experiences, so in fact, nutritional counseling and child growth follow-up are incorporated in primary health care.

Descriptors: Child Nutrition; Childcare; Primary Health Care; Research, Qualitative; Nursing Primary Health Care.

\section{RESUMO}

Introdução: Aconselhamento nutricional e acompanhamento do crescimento são prioritários na assistência à criança, porém, ainda não estão plenamente incorporados na atenção básica. Objetivo: Conhecer as dificuldades para realizar aconselhamento nutricional e acompanhamento do crescimento infantil, na perspectiva de profissionais de saúde. Método: Estudo qualitativo, fundamentado no referencial de Donabedian, desenvolvido com 53 profissionais de saúde da atenção básica. Dados foram obtidos por grupos focais e submetidos à análise de conteúdo. Resultados: As principais dificuldades para o aconselhamento nutricional reuniram-se na categoria 'percepções e crenças relacionadas à alimentação infantil'. Para o acompanhamento do crescimento, as categorias 'problemas de infraestrutura e funcionamento dos serviços de saúde' e 'manutenção do modelo médico hegemônico' representaram as principais dificuldades. Considerações finais: Além de investimentos na infraestrutura, é imprescindível que capacitações em serviço considerem crenças e experiências dos profissionais para que, de fato, o aconselhamento nutricional e acompanhamento do crescimento infantil sejam incorporados na atenção básica.

Descritores: Nutrição da Criança; Cuidado da Criança; Enfermagem de Atenção Primária; Pesquisa Qualitativa; Atenção Primária à Saúde.

\section{RESUMEN}

Introducción: El asesoramiento nutricional y el acompañamiento del crecimiento son prioridad en la atención del niño aunque todavía no estén plenamente incorporados en la atención básica. Objetivo: Conocer las dificultades para desempeñar el asesoramiento nutricional 
y el acompañamiento del crecimiento infantil según la perspectiva de los profesionales de la salud. Método: Estudio cualitativo, basado en el referencial de Donabedian, desarrollado con 53 profesionales de la salud en la atención básica. Los datos se obtuvieron mediante grupos focales y se sometieron al análisis de contenido. Resultados: Las principales dificultades sobre el asesoramiento nutricional se reunieron en la categoría 'percepciones y creencias relacionadas a la alimentación infantil'. En el acompañamiento del crecimiento, las categorías 'problemas de infraestructura y funcionamiento de los servicios de salud' y 'mantenimiento del modelo médico hegemónico' representaron las principales dificultades. Consideraciones finales: Además de la necesidad de invertir en infraestructura, es imprescindible que las capacitaciones en el servicio consideren las creencias y experiencias de los profesionales para que, de hecho, el asesoramiento nutricional y el acompañamiento del crecimiento infantil sean incorporados a la atención básica.

Descriptores: Nutrición del Niño; Cuidado del Niño; Enfermería de Atención Primaria; Investigación Cualitativa; Atención Primaria a la Salud.

\section{CORRESPNDING AUTHORＣlaudia Nery Teixeira PalomboＥ-mail: claudiapalombo@usp.br}

\section{INTRODUCTION}

Changes in food consumption behavior are one of the greatest problems in public healthcare nowadays on the world scenario. People in general have decreased their consumption of healthy foods, such as cereals and whole-grain products, as beans and vegetables, and have increasingly added more processed or ultraprocessed products, rich in saturated fats, sodium, and refined carbohydrates ${ }^{(1)}$. These changes have directly affected the nutritional profile of the general population, including important reflections on the health of children, such as increased nutritional disturbances and their consequences. There are an estimated 42 million overweight children under the age of five years old and even 156 million who suffer from chronic malnutrition ${ }^{(2)}$. Overweight and malnutrition affects $7.3 \%$ people and $7.0 \%$ of children in Brazil in this age range, respectively ${ }^{(3)}$.

There are enough evidences showing that nutritional disorders in childhood is linked to increased mortality, infectious diseases, decreased growth, and psychomotor development, decreased educational achievement, and lower productive capacity in adulthood ${ }^{(4)}$.

For these reasons, based on the scope of health assistance for children in primary health care, nutritional counseling and growth follow-up are emphasized - as this is our focus in this study - exactly because early detection of nutritional changes makes interventions possible in a timely manner and contributes to providing the opportunity so the child is provided the opportunity to fully develop his/her potential(5).

Healthy eating habits in childhood are known to constitute the basis for achieving the maximum growth and development potential. Health professionals, especially the nursing staff, and community healthcare agents, take on an important responsibility in fostering maternal practices, guiding choices, preparation, and supplying foods that are healthy, convenient, and based on cultural aspects of the population ${ }^{(6-7)}$.

Regarding child growth follow-up, this has been recommended as the main route in children's healthcare since the decade of the 1970s, remaining as an important initiative for reducing morbid-mortality and promoting healthy children ${ }^{(5)}$. Besides that, it is also one of the quality indicators on children's health assistance in the context of primary health care in the National Healthcare System ${ }^{(8)}$.

In spite of being considered as low-cost procedures and easily achievable in healthcare services, studies have shown diverse problems in putting such practices into effect, such as the scarcity of knowledge, and the unpreparedness of healthcare professionals to deal with maternal breastfeeding ${ }^{(9)}$ and feeding children under one year old ${ }^{(10)}$, infrequent records in the Child Health Booklet ${ }^{(11)}$, difficulties in performing and interpreting growth curves $^{(12)}$, as well as service infrastructure problems, as the minimum equipment, such as scales and anthropometers are unavailable for following up growth ${ }^{(13)}$.

All of these problems make us believe that nutritional counseling and child growth follow-up are not fully incorporated in the medical care practice. However, there is no knowledge from the perspective of primary health care professionals on these issues. Thus, the objective of this study was to become aware of the difficulties in performing nutritional counseling and child growth follow-up, from the perspective of primary health care professionals.

\section{METHOD}

\section{Ethical aspects}

All the recommended ethical requirements for research on human beings have been assured. There was a greater project that had as objective to evaluate the effect of training on nutritional counseling in professional practices, nutrition, growth, and child development; this was approved by the Research Ethics Committee and the Municipal Health Board. After presenting the objectives from the study and clarifications, all the health professionals who accepted participation in the study signed the Consent Form.

\section{Theoretical framework}

The study was based on the evaluation of the quality of the healthcare proposed by Avedis Donabedian, which follows the triad: Structure, Process, and Result. Structure is related to conditions and physical, human, and organization resources, on which healthcare is established, including facilities, equipment, funding, and quality of labor; Process refers to the interrelationship between the care provider and care receiver and this involves the entire dynamics of healthcare; and, the Result is the product of assistance ${ }^{(14)}$.

\section{Type of study}

Exploratory and descriptive research with qualitative approach.

\section{Methodological procedures}

The study was conducted in a small-sized town in the state of São Paulo, with an estimated population of 48 thousand 
inhabitants and in a primary health care network composed by 12 health units from which eight of them were traditional basic units, three Family Health Strategy units, and one was a mixed unit. At the time the study was performed, there were 85 primary health care professionals (13 physicians, 12 nurses, 26 nursing technicians/nursing assistants - NA, and 32 community health agents - CHA) who were linked to the municipal basis care network.

All the health professionals were invited to participate in a training course on nutritional counseling and research. Even though the training workshop scheduling had been organized by the Municipal Health Board so that all professionals could participate, and thus it would not interfere in attending at the health units, the study effectively counted on the participation of 53 professionals ( $62.4 \%$ of the total number), as there were 11 nurses, $14 \mathrm{NA}$, and $28 \mathrm{CHA}$. The $\mathrm{CHA}$ were included as they were part of the primary health care teams, and due to their important role in promoting the health of children, especially in the recommendation of appropriate and healthy eating practices ${ }^{(6-7)}$. No physicians participated in the study, justified by their impossibility to organize their scheduling.

Four training workshops were held on nutritional counseling in the period from September /2013 to February/2014, with a total of 16 hours of classes spread out on two non-consecutive days. The following themes were covered: ten steps for healthy eating for children under two years old, communication techniques for nutritional counseling, growth evaluation and child development, main nutritional disorders in childhood and using the Child Health Booklet.

\section{Collection and organizing data}

The data from this study have been collected during the training workshops on nutritional counseling through focal groups, a technique which allows the collection of the perception from participants on a specific subject, in sessions with groups composed by 5 to 15 participants, with a moderator who introduces subjects, so that the group is exposed to ideas and opinions. Thereby, more in-depth contents, including diversified answers and a wealth of details and information ${ }^{(15)}$.

At the end of each workshop period (morning and afternoon), the participants were invited to discuss their experiences on the work routines based on a leading subject that had been unfolded from each subject covered in the training: "What difficulties have you faced in performing the nutritional counseling and growth follow-up provided in child assistance?"

There was a total of 16 focal groups held lasting around 40 minutes each, which were completely recorded, transcribed, and organized using the webQDA software support.

\section{Data analysis}

The data was submitted to the analysis of content, performed by exhaustive reading of material seeking nuclei of meaning for the identification of categories and empirical subcategories $^{(16)}$. The participants were identified by the letters $N$ (Nurse), NA (Nursing Assistant), and CHA (Community Health Agent), followed by numbers from 1 to 53 , in order to maintain anonymity.
The tag cloud technique was used for aiding in data analysis, making it possible to construct a figure composed by different sized words, organized from the center to the borders, based on the frequency of the appearance in the analyzed text. The figure made possible to perform a graphic validation of the content analysis and it can be easily performed through internet sites, such as Tagul, used in this study (https://tagul.com).

\section{RESULTS}

The 53 health professional participants in the study were female, ranging from 25 to 58 years old and who had worked in primary health care for 4.5 years on an average. Only two participants commented that they had received some healthcare training on child feeding.

Chart 1 displays the Process and Structure components based on the categories and subcategories extracted from the content analysis. The Result component was not identified in the analysis.

Chart 1 - Evaluation components, content analysis categories, and subcategories based on the target groups, a small-sized town in the São Paulo State, Brazil, 2013-2014

\begin{tabular}{|l|l|l|}
\hline Evaluation component * & Categories & Subcategories \\
\hline Difficulties for performing nutritional counseling \\
\hline Process & $\begin{array}{l}\text { Perceptions } \\
\text { and beliefs } \\
\text { related to } \\
\text { child feeding }\end{array}$ & $\begin{array}{l}\text { Social, economic, and } \\
\text { cultural conditions of } \\
\text { the population } \\
\text { Mothers working } \\
\text { outside of the home } \\
\text { Consumption of }\end{array}$ \\
\hline Difficulties in following up child growth & $\begin{array}{l}\text { industrialized foods } \\
\text { Personal experiences in } \\
\text { child feeding }\end{array}$ \\
\hline Structure & $\begin{array}{l}\text { Infrastructure } \\
\text { and } \\
\text { healthcare } \\
\text { And the } \\
\text { operation } \\
\text { of health } \\
\text { services }\end{array}$ & $\begin{array}{l}\text { Inadequate physical care } \\
\text { structure }\end{array}$ \\
$\begin{array}{l}\text { Not enough equipment } \\
\text { and printed forms for } \\
\text { serving the population } \\
\text { Conflicts among mothers } \\
\text { and professionals related } \\
\text { to the healthcare unit } \\
\text { organization/operation }\end{array}$ \\
\hline Structure and Process & $\begin{array}{l}\text { Maintenance } \\
\text { of the } \\
\text { hegemonic } \\
\text { medical } \\
\text { model }\end{array}$ & $\begin{array}{l}\text { Valorization of medical } \\
\text { assistance } \\
\text { Devalorization of } \\
\text { Nursing and Community } \\
\text { Health Agents }\end{array}$ \\
\hline
\end{tabular}

Note: *Based on the evaluation reference of the quality of the healthcare proposed by Avedis Donabedian, which is based on the following triad: Structure, Process, and Result ${ }^{(14)}$.

Regarding the difficulties in performing nutritional counseling, content analysis proved that the category 'Perceptions and beliefs related to child feeding' is related to the Process component. The 'infrastructure healthcare' and the 'operation 
of health services' were related to the Structure component, and 'Maintenance of the hegemonic medical model' category was highlighted, when performing the growth follow-up related to the Structure and Process components.

\section{Perceptions and beliefs related to child feeding}

Professionals have pointed out the difficulties for performing nutritional counseling in this category, referring to social, economic, and cultural conditions of the population, especially related to mothers working outside of the home and the consumption of industrialized foods. Besides that, the respective personal experiences in child feeding were also highlighted as relevant factors in such practices. These themes add constitutive elements from the interrelation between the provider and the receiver of healthcare and, therefore, are referred to as the Process component.

The following statements show, from the perspective of professionals, the precarious socioeconomic conditions that compromise the acquisition and diversification of foods in families, and also what constitutes a limiting factor for promoting children's health:

It is not what the people eat, as they eat badly, it is difficult for them to get food where I work [...]. There is rice, beans, but there is very little diversification [...]. There are fortified flours, but access to these products is not available to the majority of the population, they are not included in basic food staples, thus, I think this factor impacts families a great deal. (N2)

(regarding the high prevalence of anemia among children) There are a great number of mothers giving Iron Sulfate. But food is difficult to find inside the home, the mother does not serve the necessary food, we try to do something, but it doesn't just depend on us. (CHA47)

Insertion of women in the job market is perceived by professionals as a negative aspect for caring for their children's food, as working mothers who work away from their homes need to look for practical foods, easy handling, and fast to prepare:

It is much easier to arrive home and just give snack food than to wash a vegetable, stir fry those vegetables, and then wait for them to cook, because mothers work jobs outside their homes [...]. (CHA29)

Children eat a great deal of junk foods, and it is not just because the conditions are lacking for buying foods, but due to the busy lives of working mothers, then sometimes children spend the entire day just drinking milk. (NA22)

Industrialized (processed) foods are not nutritious from the point-of-view of health professionals, such as packaged snack foods, sweets, and soft drinks, as these are low-cost foods, easily to get, and highly practical, and accepted very well by children, as this facilitates and contributes to the excessive consumption of these products:

[...] then, these cheaper packaged snack foods seem like Styrofoam, the population can easily access them and they kill one's hunger [...] it is practical, there is a stand selling all over the place, a snack bar, in the supermarket. (N7)

Therefore, I think, snack foods are extremely available, cheap, and unfortunately all children love them. Put a package of snack foods and a plate of food in front of a children, they will always choose a snack food. (N1)

The choice and supply of foods to children are not only an economic issue, but this also involves family habits, as well as the difficulty in dealing with food refusal from children regarded by professionals. In their perception, parents offer the most easily accepted foods to their children and, regarding this, the professional feels impotent:

[...] it is much more convenient for you to give a snack food or a cup of Dannon yogurt then preparing a vegetable, it is much easier to give them what they like [the children] then insisting on what is correct. (NA15)

[...] this is not based on a financial reason, there is no lack of guidance, because I say we shouldn't give candy drops, lollipops, snack foods, but it does not good for us to say this. (N3)

Professionals also have their own personal and family experiences in children's food, and do not always agree with the recommendations regarding recommended eating practices:

[...] I instruct the mother technically, but I don't agree, because I raised my children differently, the old fashioned way, as my mother, my grandmother raised us, and they were healthy, thus, I think we put too many demands on the mothers and then we end up making them keep their distance, I give instructions the way they have to be, but I do not agree. (CHA43)

I had always worked when my children were little, so they were raised on cow's milk, since they were born, I had already been giving them water, they were well-fed, but they always had their junk food, so when a mother tells me that she gave water to a 4-month old child, I don't say it is right, but I don't disagree. (NA25)

In this category, the words expressed in the word cloud were: 'Beliefs', 'Dogmas', 'Disagreement', and 'Values' (Figure 1).

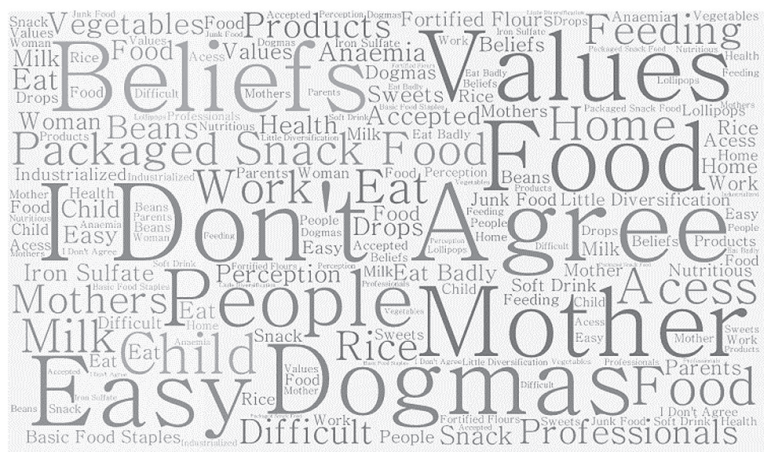

Figure 1 - This is the word cloud for the 'Perceptions and beliefs related to child feeding' category' 
Problems with infrastructure and the operation of the healthcare services

Inadequate physical healthcare facilities, not enough equipment, and printed forms for serving the population are considered as aspects making growth follow-up difficult of children, as well as conflicts among mothers and professionals related to the organization/operation of a healthcare unit, which are referred to as the Structure component.

The lack of physical space for performing adequate assistance, not enough supplies, and obsolete equipment, such as pediatric scales, are examples of the inadequate healthcare service infrastructure, such as shown in the following excerpts:

[...] we have only one room for doing everything in my Unit [...] and there are mothers who live on farms around $30 \mathrm{~km}$ from the healthcare clinic, then they arrive there and if I end up bandaging them, if I can perform any other procedure [...]. (NA14)

[The scale] resource is very bad at my unit, so, it is impossible for me to leave the room [consulting office], there is still no digital scale, so it takes 5 minutes to weigh a child [...]. (N5)

The lack of printed forms and other instruments for registering the healthcare follow-up of children in healthcare units was also mentioned as a problem. The Child Health Booklet $(\mathrm{CHB})$, as well as being unavailable in the units, in the perception of professionals, the mothers do not recognize them as being important to the health of their children and do not adequately care for this instrument:

[...] there are children who do not get vaccinated in the hospital, thus the child is first vaccinated at the local healthcare clinic and I do not have that booklet. [N7]

[...] the mother does not bring the [the $\mathrm{CHB}$ ] to every appointment [...]. (N2)

Another difficulty is the organizational condition of the services that causes conflicts among the mothers and the professionals, especially regarding the appointment schedules for the population. According to the professionals, the mothers do not abide by the operating regulations of the healthcare units and they want immediate attention, as exemplified by the following excerpts:

The mother says: 'You see, I have to start working at 1 p.m., is there any way you can see me now? Because she arrived there and wants to be treated exclusively and seen first and there are other people waiting [...]. (NA15)

It is exactly like that, there where I work as it is difficult to get there, they go precisely at their lunchtime schedule, but if you make an exception for one, you have to make an exception for every one and then this becomes an obligation, every day, and always. It is so complicated! It doesn't matter how much you give them instructions, and display schedule posters [...]. (NA14)
Figure 2, displays an image generated by the word cloud technique, corroborating with the result from the content analysis related to this category, highlighting the words 'Problem', 'Structure', and 'Unit'.

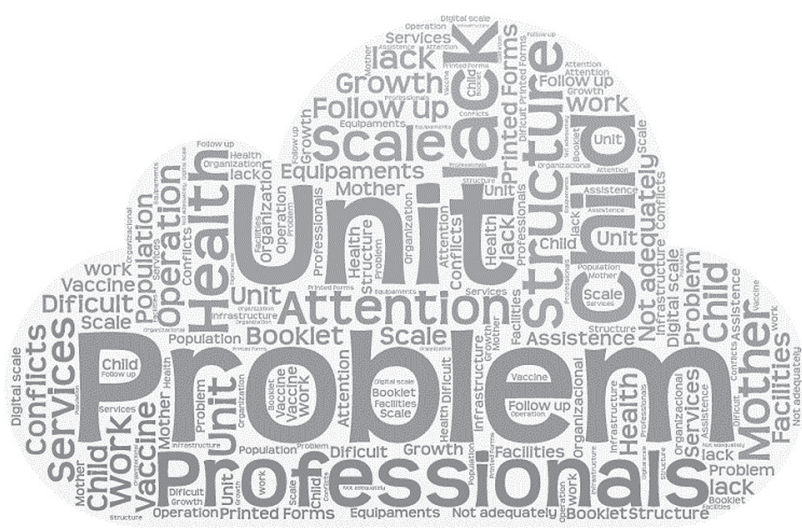

Figure 2 - This is the word cloud for the 'Infrastructure problems and healthcare service operation' category

\section{Maintenance of the hegemonic medical model}

There is esteem for medical assistance and a lack of esteem for Nursing and $\mathrm{CHA}$ by the population, which is linked to the Process component. This esteem and lack of esteem also occurs among the professionals themselves and, as these refer to human and organizational resources established in healthcare, as they are integrated in the Structure component.

The following excerpts show that, from the professional perspective, the population only recognizes the doctor as the professional capable of caring for their health:

\begin{abstract}
I had an experience with a pregnant woman yesterday, I explained to her the food she needed to have, the necessary care for her pregnancy, then she said to me the following: 'alright, now I will see the doctor and see what he tells me, because you are telling me a lot of things and he always tells me everything is alright' [...] that was like a bucket of cold water. (NA 19)
\end{abstract}

The CHA also do not feel recognized and appreciated by the population, as, during the visits to households, they notice a lack of cooperation from mothers, even for consulting the $\mathrm{CHB}$ :

Ah, we ask them to show the $(\mathrm{CHB})$ card every time, but they say that they have lost it, they are waiting and they don't find it, or that they didn't have time to look for it right then. (CHA 32)

Then, the mothers say: 'ah, I don't have time to look for it right now, I am busy, I don't want to show (the CHB) card, I am not obliged to [...] you are not a nurse, then you don't need to see it'[...]. (CHAS30)

Based on the following excerpts, it is possible to see how the follow-up appointment of the child is focused on the 
doctor, as the nursing personnel are only assigned to weighing and measuring the child:

I don't even use those printed forms (the printed forms for the growth medical history chart), I didn't even know where they were and the doctor locks them in the cabinet [...]. (N7)

[...] in my unit, the pediatrician wants us to weigh and measure the child [...] but we don't have access to the baby scale, it stays in her consulting office. (N4)

The nurses also do not consider the importance of their work, attributing the doctor the 'power' and the responsibility for growth evaluation:

[...] I, for example, check to see if the child has 'grown' or has 'not grown' speaking to the mother). Sometimes, the mother says this: 'my God, he/she has not grown? And then I say: 'but he/she has gained weight' [...] then, the child does not necessarily grow every month. This is from the nursing point of view, but then, inside the (doctor's) consulting office, I expect the doctor to perform an evaluation. (N2)

I like to make annotations in the CSC, but I am afraid the doctor will not see them during the appointment. (N5)

[...] the doctor is not going to make annotations in two different places and for this reason; we make annotations on the medical history report. (N3)

The word cloud technique ratified the analysis in this category, expressed the words 'Physician', 'Health', 'Child', 'Power', as shown in Figure 3.

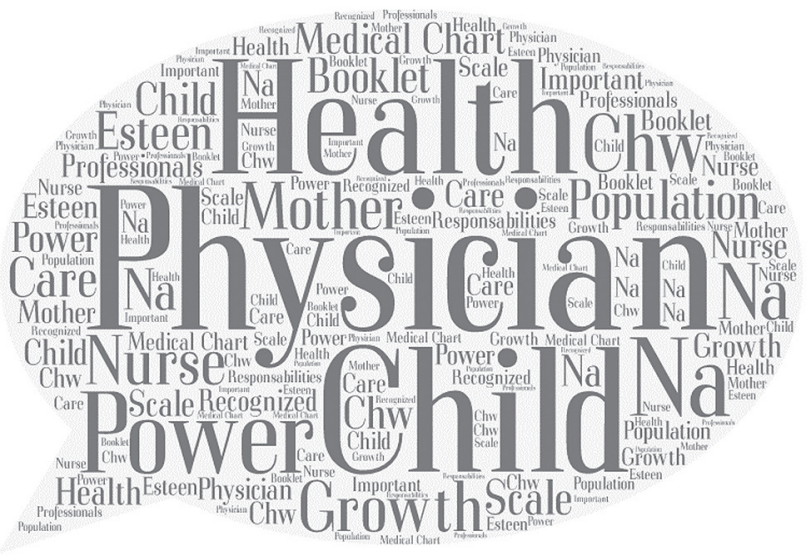

Figure 3 - This is the word cloud for the 'Mainenance of the hegemonic medical model' category

\section{DISCUSSION}

The objective of this study was to know the difficulties for performing nutritional counseling and following up the child growth from the perspective of professionals in the primary health care. The results have shown that the main difficulties in nutritional counseling refer to perceptions and beliefs related to child feeding, highlighted by the word cloud: 'Beliefs', 'Dogmas', 'Values', 'Disagreement'. Related to growth follow-up, the difficulties are concentrated on the problems of infrastructure and organization of healthcare services, as well as in the maintenance of the medical hegemonic model.

Based on the Donabedian reference ${ }^{(14)}$, those results are related to the Process and Structure components, the same way as found in the study performed by physicians in the Federal District that, when evaluating the barriers for promoting healthy eating in professional practice, it also expressed the relevance of sociocultural aspects of the population, inadequate healthcare services, and the lack of professional training ${ }^{(17)}$.

Social, economic, and cultural conditions were verified, as the insertion of women in the job market and the usage of ultra-processed foods interfere with nutritional counseling and generate a feeling of impotence. Families do not have the purchasing power to buy diversified foods and thereby serve monotonous foods to children, products from the basic food staples. Meanwhile, they revealed that the consumption of ultra-processed foods is generalized, due to their practicality, easy access to children, and low cost. In fact, in Brazil, studies have shown that these aspects justify the option for families for such foods, including the lowest poverty levels of the population, thereby reducing the consumption of natural foods or minimally processed ${ }^{(18)}$.

Furthermore, bad eating habits and the consumption of ultra-processed foods have been responsible for the increase in weight among all age groups ${ }^{(1)}$, as well as chronic diseases associated to this, thereby causing a great impact on the health of the population ${ }^{(19)}$. Such aspects confirm the importance of nutritional counseling, especially during the first years of life.

On the other hand, the possibility for improving the purchase power of families through the insertion of women in the job market negatively interferes in the eating habits of children, from the professional perspective, as mothers start buying prepared, practical, and fast preparation foods for consumption. The initial basis of the studies explore the specific association of a mother working outside of the home on the growth and child feeding practices, possibly due to the diversity of the related factors, such as maternal educational levels, the type and connection to the job, the transportation time, the amount of time the mother stays away from home, among other factors. However, the study evaluated the connection considering the practice of exclusive maternal breast feeding to maternal characteristics that identified the negative relationship to working outside of the home, thereby, confirming lower prevalence of exclusive breast feeding by those mothers ${ }^{(20)}$. In India, there was a qualitative study performed on working mothers that highlighted, from the mothers' perspective, working outside of the home compromised caring for child feeding ${ }^{(21)}$.

Professionals emphasized cultural aspects and family habits, as well as the subject of economic aspect, as another difficulty for dealing with child feeding. In fact, parents exert an influence on the formation of eating habits in small children, as well as genetics, regarding exposure to tastes and textures, connected to cultural characteristics ${ }^{(22)}$. Besides that, the parents are responsible for supplying foods and are affected by the influence from the 
perception that they have based on the nutritional condition of the child. Based on this scope, we wish to stress that there are mothers who find it difficult to recognize the nutritional condition of their children, especially those who are overweight, underestimating $^{(23)}$, that way they can encourage increased food consumption.

There are even the perceptions and beliefs of professionals related to child alimentation, thus it is important to stress that although they do not agree with some recommendations, professionals confirm their experiences and beliefs do not exert an impact on their practices in nutritional counseling. There has been a conflict noticed between real life experience and scientific knowledge, as it is possible that the former prevails. Qualitative study developed by physicians and nurses on the difficulty encountered in dealing with alimentation problems also identified conflicts among theoretical knowledge and the practical experience of professionals ${ }^{(24)}$. However, it is necessary to consider issues related to alimentation involve memories and awaken different feelings and, maybe due to this, these aspects have been insufficiently explored.

Regarding the difficulties in following up child growth, there are precarious conditions in the facilities and a lack of equipment, including printed forms, from the professional perspective, as these were pointed out as recurrent problems in healthcare services. Surprisingly, there have been studies performed in 41 municipalities for a decade in seven States in the Northeast and Southern regions of Brazil that have already reported on their precariousness and faulty supply of physical infrastructure at healthcare units ${ }^{(13)}$, as this seems to still be a reality nowadays.

Quantifying the portion of the Structural component based on the final quality of healthcare provided is not a simple task, but there is evidence that the quality of the healthcare is better when the Structure is more adequate ${ }^{(14)}$. The study has evaluated the perception of 397 Canadian nurses on the quality of the healthcare and the professional satisfaction showed that the working environments equipped with adequate structure is directly related to professional satisfaction in healthcare services, which favors the quality of the healthcare ${ }^{(25)}$. Thus, so that growth follow-up is completely incorporated in primary health care, it is necessary to make investments in the infrastructure of services, as well as professional training.

Another aspect revealed by professionals, such as the difficulty in growth follow-up that referred to the lack of $\mathrm{CHB}$, although, the filling in and the usage of this instrument do not take place adequately, especially related to growth and development charts (11). Additionally, based on the perception of professionals, mothers do not use the $\mathrm{CHB}$ and do not value them, the same way the professionals themselves do, as that contributes to following up child growth that does not occur as recommended, thereby hindering the early detection of easily avoidable problems.

The results also showed discontentment and conflicting situations among mothers and professionals arising from the organization and operation of the healthcare services, especially regarding the pressure for an immediate appointment. Such dissatisfaction caused by the flow of care provided and conflicting relations among professionals and healthcare users represent a recurring condition and a complex solution, as verified by the systematic review of qualitative studies that analyzed humanization practices in primary health care ${ }^{(26)}$.
The valorization of the physician, in detriment to other staff members, such as nurses and $\mathrm{CHA}$, stressed in what has been said and the word cloud, as well as the other difficulty concerning nutritional counseling and growth follow-up. In fact, the hegemonic model, which is centralized in medical practice, does not valorize nor recognize the nucleus of nursing competencies and their autonomy in their care, as this makes this professional more removed from the healthcare productive process ${ }^{(27)}$. However, the sustainment of this model has been verified and also is maintained by the professionals themselves, that is reinforced when they cannot make clinical decisions and do not take on the responsibility of healthcare within their legal powers. It is possible that such behavior is a remnant from, the historical development that has characterized nursing as a submissive practice ${ }^{(28)}$. It is worthwhile to stress that no doctor has participated in training, although the administrators have organized schedules for everyone to participate.

Related to $\mathrm{CHA}$, as they reside in the same territory, this is added to the fact, as these professionals suffer from embarrassment and resistance from the population in performing their activities $^{(29)}$. Besides that, there is evidence that, although they represent the link between the community and healthcare services, the $\mathrm{CHA}$ themselves do not recognize their importance, thereby detracting from and limiting their initiatives ${ }^{(30)}$. The entirety of the healthcare of a child demands, however, care from all professionals, each on fulfilling his/her own mission, with shared action, to understand the peculiar growth characteristics and the development of the child.

\section{Study limitations}

Considering that nutritional counseling involves the social and individual context of families, only being aware of the difficulties from the professional perspective can be a limitation to this study. However, the results point out the need for further studies to evaluate the perspective from multiple players implied in this process, such as administrators, physicians, nutritionists, and the mothers/caregivers/families themselves.

\section{Contribution to the field of nursing}

The results have brought out that, besides the healthcare training courses, there needs to be investments in basic infrastructure, so that, the nurses in fact and their staff incorporate nutritional counseling and child growth follow-up in their routine services.

\section{FINAL CONSIDERATIONS}

Difficulties have been verified for providing nutritional counseling and growth follow-up referring to the perceptions and beliefs of professionals regarding eating practices of the population and their own experiences in child feeding, as well as the problems in infrastructure and the operation of services, and also the maintenance of the medical hegemonic model.

In order to achieve effective incorporation of nutritional counseling and child growth follow-up in the routine primary health care services and, thus improve the overall healthcare of children, there must be investments focused on the Structure component. However, healthcare training is indispensable, 
having a critical and reflective approach on healthcare professional practice and, above all, consider their beliefs and personal experiences, as qualified professionals inserted in healthcare services along with an adequate structure results in Process enhancements, or in other words, in the healthcare dynamics and, consequently, in Results, healthy children.

\section{FUNDING}

This research was funded by the São Paulo Research Foundation (process \# 2011/509309) and the National Council of Scientific and Technological Development (process \# 480255/2012-1).

\section{REFERENCES}

1. Popkin BM, Adair LS, Ng SW. The global nutrition transition: The pandemic of obesity in developing countries. Nutr Rev [Internet]. 2012 [cited 2016 May 05];70(1):3-21. Available from: https://www.ncbi.nlm.nih.gov/pmc/articles/PMC3257829/pdf/nihms336201.pdf

2. UNICEF/WHO/World Bank Group. Levels and trends in child malnutrition. WHO: Geneva, [Internet] 2016 [cited 2016 May 05]. Available from: http://www.who.int/nutrition/publications/jointchildmalnutrition_2016_estimates.pdf

3. Brasil. Ministério da Saúde. Pesquisa Nacional de Demografia e Saúde da Criança e da Mulher - PNDS, 2006: dimensões do processo reprodutivo e da saúde da criança[Internet]. Brasília: Ministério da Saúde; 2009 [cited 2016 May 05]. 302p. Available from: http://189.28.128.100/dab/docs/portaldab/documentos/pesquisa_demografia.pdf

4. Victora CG, Adair L, Fall C, Hallal PC, Martorell R, Richter L, et al. Maternal and child undernutrition: consequences for adult health and human capital. Lancet[Internet]. 2008 [cited 2016 May 05];371:340-70. Available from: http://www.thelancet.com/ pdfs/journals/lancet/PIIS0140-6736(07)61692-4.pdf

5. Brasil. Ministério da Saúde. Portaria № 1.130 de 5 de agosto de 2015. Institui a Política Nacional de Atenção Integral à Saúde da Criança (PNAISC) no âmbito do Sistema Único de Saúde (SUS)[Internet]. 2015[cited 2016 May 05]. Available from: http://bvsms. saude.gov.br/bvs/saudelegis/gm/2015/prt1130 0508 2015.html

6. Brasil. Ministério da Saúde. Política Nacional de Atenção Básica[Internet]. Brasília: Ministério da Saúde; 2012 [cited 2016 May 05]. 110p. Available from: http://189.28.128.100/dab/docs/publicacoes/geral/pnab.pdf

7. Brasil. Ministério da Saúde. Orientações para avaliação de marcadores de consumo alimentar na atenção básica[Internet]. Brasília: Ministério da Saúde; 2015 [cited 2016 May 05]. 33p. Available from: http://189.28.128.100/dab/docs/portaldab/publicacoes/ marcadores_consumo_alimentar_atencao_basica.pdf

8. Brasil. Ministério da Saúde. Programa Nacional de Melhoria do Acesso e da Qualidade da Atenção Básica (PMAQ): manual instrutivo Brasília: Ministério da Saúde, [Internet]. 2012 [cited 2016 May 05]. 62p. Available from: http://189.28.128.100/dab/docs/publicacoes/ geral/manual_instrutivo_pmaq_site.pdf

9. Almeida JM, Luz SAB, Ued FV. Support of breastfeeding by health professionals: integrative review of the literature. Rev Paul Pediatr[Internet]. 2015 [cited 2016 May 05];33(3):355-62. Available from: https://www.ncbi.nlm.nih.gov/pmc/articles/ PMC4620964/pdf/0103-0582-rpp-33-03-0355.pdf

10. Alves TD, Pereira GA, Bonfim SFSF, Javorski M, Vasconcelos MGL, Leal LP. Prática dos enfermeiros no manejo da alimentação de crianças menores de um ano de idade. Rev Enferm UFPE[Internet]. 2011 [cited 2016 May 05]. 5(spe):2651-9. Available from: http://www.revista.ufpe.br/revistaenfermagem/index.php/revista/article/viewFile/2388/pdf_792

11. Abud SM, Gaíva MAM. Records of growth and development data in the child health handbook. Rev Gaúcha Enferm[Internet]. 2015 [cited 2016 Jun 01];36(2):97-105. Available from: http://dx.doi.org/10.1590/1983-1447.2015.02.48427

12. Abreu T, Viana L, Cunha C. Challenges in utilization of Child Health Booklet: between real and ideal. JMPHC[Internet]. 2012 [cited 2016 Jun 01];3(2):80-3. Available from: http://www.jmphc.com.br/saude-publica/index.php/jmphc/article/.../142/144

13. Facchini LA, Piccini RX, Tomasi E, Thumé E, Silveira DS, Siqueira FV, et al. Performance of the PSF in the Brazilian South and Northeast: institutional and epidemiological Assessment of Primary Health Care. Ciênc Saúde Colet[Internet]. 2006 [cited 2016 Jun 01];11(3):669-81. Available from: http://dx.doi.org/10.1590/S1413-81232006000300015

14. Donabedian A. Quality assurance. Structure, process and outcome. Nurs Stand[Internet]. 1992 [cited 2016 Jun 01];7(11SupplQA):4-5. Available from: https://www.ncbi.nlm.nih.gov/pubmed/1489693

15. Polit DF, Beck CT. Fundamentos de pesquisa em enfermagem: avaliação de evidências para a prática em enfermagem. 7a ed. Porto Alegre: Artmed; 2011.

16. Minayo MCS. O desafio do Conhecimento: pesquisa qualitativa em saúde. $2^{\text {a } e d . ~ R i o ~ d e ~ J a n e i r o-S a ̃ o ~ P a u l o: ~ A b r a s c o-H u c i t e c ; ~}$ 2000.

17. Oliveira KS, Silva DO, Souza WV. Barriers to the promotion of healthy eating perceived by doctors. Cad Saúde Colet[Internet]. 2014 [cited 2016 Jun 01];22(3):260-5. Available from: http://dx.doi.org/10.1590/1414-462X201400030007

18. Martins APB, Levy RB, Claro FM, Moubarac JC, Monteiro CA. Increased contribution of ultra-processed food products in the Brazilian diet (1987-2009). Rev Saúde Pública [Internet]. 2013 [cited 2016 Jun 01];47(4):656-65. Available from: http://www. 
scielosp.org/pdf/rsp/v47n4/en_0034-8910-rsp-47-04-0656.pdf

19. Otto MCO, Afshin A, Micha R, Khatibzadeh S, Fahimi S, Singh G, et al. The Impact of Dietary and Metabolic Risk Factors on Cardiovascular Diseases and Type 2 Diabetes Mortality in Brazil. PLoS ONE [Internet]. 2016 [cited 2016 Jun 01];11(3):e0151503. Available from: http://journals.plos.org/plosone/article?id=10.1371/journal.pone.0151503

20. Damião JJ. [Influence of mothers' schooling and work on the practice of exclusive breastfeeding]. Rev Bras Epidemiol[Internet]. 2008 [cited 2016 May 05];11(3):442-52. Available from: http://www.scielo.br/pdf/rbepid/v11n3/10.pdf Portuguese.

21. Nair M, Ariana P, Webster P. Impact of mothers' employment on infant feeding and care: a qualitative study of the experiences of mothers employed through the Mahatma Gandhi National Rural Employment Guarantee Act BMJ Open[Internet]. 2014 [cited 2016 May 05];4:e004434. Available from: http://bmjopen.bmj.com/content/4/4/e004434.abstract

22. Harris G. Development of taste and food preferences in children. Clinical Nutr Metabolic Care[cited 2016 May 05];11(3):315-9. Available from: https://www.ncbi.nlm.nih.gov/pubmed/18403930

23. Duarte LS, Fujimori E, Toriyama ATM, Palombo CNT, Borges ALV, Kurihayashi AY. Brazilian Maternal Weight Perception and Satisfaction with Toddler Body Size: a study in Primary Health Care. J Ped Nursing[Internet]. 2016 [cited 2016 Jun 01];31:1-8. Available from: https://www.ncbi.nlm.nih.gov/pubmed/27132799

24. Boog MCF. Dificuldades encontradas por médicos e enfermeiros na abordagem de problemas alimentares. Rev Nutr[Internet]. 1999 [cited 2016 Jun 01];12(3):261-72. Available from: http://dx.doi.org/10.1590/S1415-52731999000300006

25. Laschinger HKS, Zhu J, Read E. New nurses' perceptions of professional practice behaviours, quality of care, job satisfaction and career retention. J Nurs Manag[Internet]. 2016 [cited 2016 Jun 01]; 1-10. Available from: https://www.ncbi.nlm.nih.gov/ pubmed/26932145

26. Nora CRD, Junges JR. Humanization policy in primary health care: a systematic review. Rev Saúde Pública[Internet]. 2013 [cited 2016 Jun 01];47(6):1186-200. Available from: http://dx.doi.org/10.1590/S0034-8910.2013047004581

27. Uchôa SAC, Arcêncio RA, Fronteira ISE, Coêlho AA, Martiniano CS, Brandão ICA, et al. Acesso potencial à atenção primária em saúde: o que mostram os dados do programa de melhoria do acesso e da qualidade do Brasil? Rev Latino-Am Enfermagem [Internet]. 2016 [cited 2016 Jun 01];24:e2672. Available from: www.scielo.br/pdf/rlae/v24/pt_0104-1169-rlae-02672.pdf

28. Andrade AC. Nursing is no longer a submissive profession. Rev Bras Enferm[Internet]. 2007[cited 2016 May 05];60(1):96-8. Available from: http://dx.doi.org/10.1590/S0034-71672007000100018

29. Jardim TA, Lancman S. Subjective aspects of living and working within the same community: the realities experienced by community healthcare agents. Interface[Internet]. 2009 [cited 2016 May 05];13(28):123-35. Available from: http://dx.doi.org/10.1590/ S1414-32832009000100011

30. Santos CW, Farias Filho MC. Community Health Workers: a perspective of the social capital. Ciênc Saúde Colet[Internet]. 2016 [cited 2016 Jun 01];21(5):1659-68. Available from: http://dx.doi.org/10.1590/1413-81232015215.23332015 